\title{
Characterization and Delineation of Aquifer in Part of Omoku, Rivers State, Nigeria
}

\author{
${ }^{1}$ I. Tamunobereton-ari, ${ }^{2}$ V. B. Omubo-Pepple and ${ }^{3}$ A.R.C. Amakiri \\ ${ }^{1,2,3}$ Department of Physics, Rivers State University of Science and Technology, Port Harcourt 500001, Nigeria.
}

\begin{abstract}
Hydrogeological work was carried out to providing an alternative source of portable water supply to Omoku and its environs as their major source of water which is surface water had been contaminated/polluted by oil and gas exploration, exploitation and other anthropogenic activities in the area. To obtaining reliable data and achieving the aim, geoelectric sounding method and Schlumberger array was employed with the use of a digital averaging instrument ABEM terrameter SAS 300 model that displays the resistance measurements directly with a maximum current electrode separation $(A B)$ of $100 \mathrm{~m}$. WinResist software computer iterative procedure was used, which aided to obtaining interpreted depths and resistivities from field data. The results of the geoelectric survey were tied to various lithologies by calibrating the geoelectric values with borehole data which enabled us to establish the aquiferous zones. The aquifers were located at depth of about $22 \mathrm{~m}$ to $30 \mathrm{~m}$ based soil profile and high resistivity values ranging from $3415 \Omega \mathrm{m}$ to $4555 \Omega \mathrm{m}$. The information from the findings can be successfully used to harnessing and supply safe, portable and sustainable water to the people of Omoku and its environs in Rivers State, Nigeria.
\end{abstract}

Keywords: Groundwater, aquifer, geoelectric layer, Vertical Electrical Sounding (VES)

\section{Introduction}

Water is an essential liquid to human lives and continuous existence of the ecosystem. Water has some physical characteristics that guaranteed its wholesomeness: it must be colourless, odourless, tasteless, and readily foam with soap or detergents. The human body and blood is composed of $60-75 \%$ of water as such needed enough water; at least 2-3 litres for adult to enhance the effective functioning of the circulatory and metabolic systems of the body. Safe water must be used for domestic (drinking, washing, bathing, and cooking), agricultural, industrial processes, and recreational activities. This water is gotten from sources such as: rain, snow, stream, lake, river, sea and aquifer (groundwater). Safe water is dependent on the chemical components of the water. The understanding of aquifer geometry, its characterization and delineation were the major objectives of this work.

Groundwater is an important natural resource that supplies billions of gallons of water for domestic, agriculture, industrial purposes and other uses. The known surface water bodies in the area under study are severely polluted by anthropogenic activities, as such about $85 \%$ of the population of the area now solely depends on groundwater as their source of water. Thus, harnessing and preservation of clean and safe groundwater becomes imperative. The considerable thickness of the aquifers, the high transmissivity of water through these aquifers due to the high degree of porosity and permeability and the adequate groundwater recharge capacity enhanced by the high annual rainfall in the area, makes the aquifers of the area reliable water resources that can yield and supply reasonable millions of volume of water to satisfy the water needs of the people and industries of the area through both public and private abstractions (Todd, 1959; Krivochieva and Chouteau, 2003, Tamunobereton-ari et al, 2010a; Tamunobereton-ari et al, 2010b).

The characterization and delineation of aquifer in the area becomes imperative as water samples from some existing wells and boreholes in the study area fall short of the acceptable characteristics of groundwater and during the dry season most wells and boreholes drop to a minimum yield and sometimes get dried up; perhaps due to lack of hydrogeological information of the area and improper delineation of the aquifer to facilitate the precise identification of desired aquifer before drilling and well completion for sustainable supply of potable water to the people of the area (Edlefsen, and Anderson. 1941; Tamunobereton-ari et al, 2013).

\section{The Area of Study}

Omoku is the capital of Ogba/Egbema/Ndoni Local Government Area of Rivers State in Nigeria. The Ogba/Egbema/Ndoni Local Government Area is inhabited by the three tribes Ogba, Egbema and Ndoni people. The Egbema speak their own dialect of the Igbo language, whereas Ogba speak the Ogba language while Ndoni speak dialect related to Kwale in Delta State. They are great farmers and fishermen with a rich cultural history.

The study area (Omoku) is a host to Nigerian Agip Oil Company (NAOC) and a central business hub of Orashi region of the Rivers State of Nigeria (Fig. 1). These had led to the continuous influx of associate companies and people into the area whose activities had contaminated and polluted the massive surface water 
bodies by the anthropogenic activities in the area (Alloway and Ayres, 1997; Tamunobereton-ari et al, 2010b). Aside the contamination and pollution of the surface water bodies, some persons in the area still continually depend on surface water for domestic and agricultural activities, but these surface waters always almost dry up during the dry seasons. Consequently, the need for portable and sustainable water supply in the area become intense, which necessitated the conduct of these hydrogeological and geophysical studies of the area to provide useful information to the location of productive aquifers and possible drilling of such formations for sustainable supply of potable water to meet the water needs of the ever-growing population and industries of the area since almost all now depend solely on groundwater.

\section{Materials And Method}

Vertical electric sounding (VES) method was used to obtain the data due to the simplicity of the technique, easy interpretation and rugged nature of the associated instrumentation, it is also economical, quick and effectively used in both soft and hard rock areas, which has been proven in solving most groundwater survey problems in different parts of the world (Zohdy et al, 1973; Koefoed and Dirk, 1979). This method has also been used successfully to determine saltwater-freshwater interface and the lateral extent of saltwater intrusion in the Niger Delta (Zohdy, 1968).

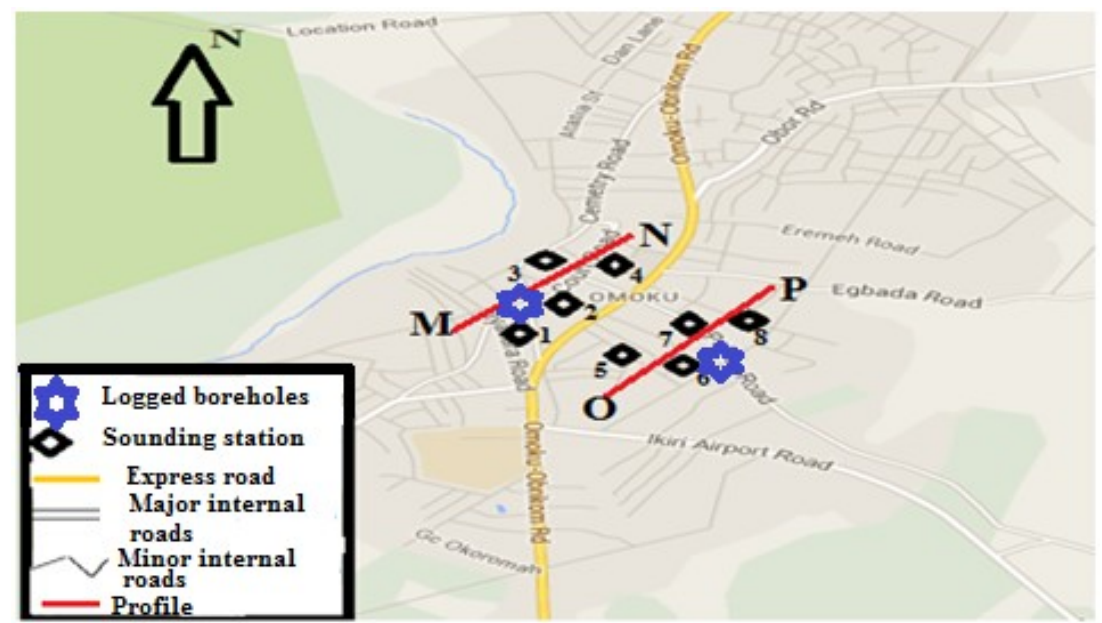

Fig. 1: Map of the Study Area (Omoku) showing the Sounding Stations (Google, 2014)

\section{Data Acquisition}

The materials used in this work are: ABEM Terrameter SAS 300 model, two reels of three core $2.5 \mathrm{~mm}$ flexible copper wire cables, four stainless metal stakes and 12 volt battery power source as shown by Fig. 2 . In this work, eight (8) stations were sounded along two profiles MN and OP on opposite side of Omoku-Obrikom express road that passes through Omoku, four (4) stations along each profile to obtain the relevant data. Station 1 was at Cemetry road, station 2 at Ihiukwu road, station 3 at Church road and station 4 at Park avenue all along profile MN, while along profile OP was station 5 at Umu Nkara street, station 6 was off Nwagbogwe street, station 7 was at Palace road and station 8 at Ogaranya Ewo street off Egbada road. Schlumberger array layout was employed for the survey because of its advantages over other arrays. In this method the fraction of total current which flows at depth varies with the current-electrode separation. The field procedure used a fixed center with an expanding spread. The presence of horizontal or gently dipping beds of different resistivities is best detected by the expanding spread (McCorkle, 1931; Koefoed and Dirk, 1979).

Quantitatively, we can see how the apparent resistivity varies for the different electrodes spread.. However, new advances in electronics technology had developed mechanism, which automatically accounts for the spontaneous potentials arising at the electrodes and considerably improves measurements accuracy (Gupta and Hanks, 1972; Barker, 1989; Banton et al, 1997). 


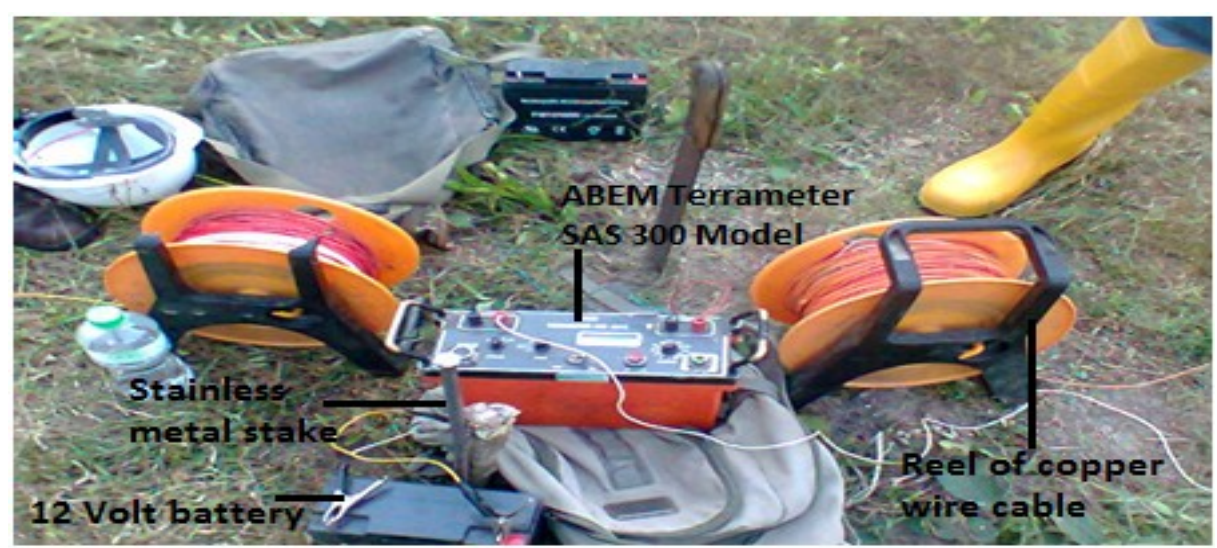

Fig. 2: Set of Vertical Geoelectric Sounding (VES) Equipment for Data Acquisition

With the Schlumberger array, the potential (MN) electrodes separation is kept constant while the current electrodes $\mathrm{AB}$ as used in this work is increased in steps. A maximum current electrode separation (AB) of $100 \mathrm{~m}$ was used in this work. In each measurement, the digital averaging instrument ABEM terrameter SAS 300 model displayed the resistance directly. The readings are made possible as the four electrodes driven into the ground are connected to $\mathrm{AB}$ and $\mathrm{MN}$ terminals of the meter through the reels of cables. This procedure was repeated for each sounding station along the marked profiles.

Also, in order to establish the lithostratigraphic sequence of the geology of the study area, two well were drilled and logged one for each profile as shown by Figures 11 and 12 to obtain relevant information for precise interpretation. Information was also obtained from existing wells and boreholes for the purposes of arriving at convincing conclusions.

\section{Data interpretation}

Vertical Electrical Sounding (VES) data interpretation was started by first plotting the apparent resistivity computed from field measurements versus electrode spacing in a WinResist software environment. The sounding curve is then compared with internally built standard curve generated by the software program, to obtain the parameters of the geoelectric layers in terms of layer resistivity, depth and thickness. For this work, the delineation of geoelectric layer and thickness was done with the software, while geological stratigraphy was carried out based on geoelectric resistivity range of lithology and the knowledge of geology of the area.

Other geoelectric parameters such as Transverse resistivity, longitudinal resistivity, Anisotropy, longitudinal unit conductance and transverse unit conductance can be computed or derived from the resistivity and thickness of the geoelectric layers delineated using the equations below.

Longitudinal unit conductance, $S_{L}=\frac{h_{i}}{\rho_{i}}$

Transverse unit resistance, $\quad T_{t}=h_{i} \rho_{i}$

Longitudinal resistivity, $\quad \rho_{L}=\frac{h_{i}}{s_{i}}$

Transverse resistivity,

$$
\rho_{t}=\frac{T_{i}}{h_{i}}
$$

Anisotropy,

$$
\lambda=\sqrt{\frac{\rho_{t}}{\rho_{L}}}=\frac{\sqrt{T S}}{h}
$$

For isotropic layer $\rho_{\mathrm{t}}=\rho_{\mathrm{L}}$ therefore $\lambda=1$

Where $h$ is the thickness of layer, $\rho$ represents resistivity of the layer

\section{Results And Discussions}

The numerical data obtained from the field geoelectric sounding for the eight stations are presented by Tables 1-8 for stations 1-8 respectively, and the corresponding VES Curves in Log-Log plots are shown by the Figs 3 - 10 below. Apparent Resistivities are plotted as ordinates while Current Electrode spacing (AB/2) as abscissas. Chart-sheet for each station; the chronological geoelectric layers and their corresponding resistivities 
(ohm $\mathrm{m}$ ), and depths (m) respectively are recorded. The line plot of the figures is a plot of apparent resistivity against $\mathrm{AB} / 2$ while the block or square shaped plot is a plot of apparent resistivity against layer thickness. The a-components of the Tables show half of the current electrode spacing $(\mathrm{AB} / 2)$, half of the potential electrode spacing (MN/2), the resistance and the apparent resistivity values. While, the b-components of the Tables show interpreted thicknesses of the geoelectric layers and the corresponding resistivities of those layers.

The data from the interpreted geoelectric layers show that the sounding stations with respect to the investigate depth of $30 \mathrm{~m}$ have 5 to 6 geoelectric layers based on resistivity variation and lithostratigraphic sequence. The knowledge of the lithostratigraphic sequences of the geology and soil profiles of the survey area enabled us to precisely establish the aquiferous zone, which is the zone with clean dense coarse sand corresponding to the depth of $17 \mathrm{~m}$ down to $30 \mathrm{~m}$ as shown by Figs 11 and 12 . From the geoelectrical crosssections of the profiles as presented by Figs 13 and 14, the best fresh water aquiferous layer is the last layer of the sequence based on the soil profile of clean dense coarse sand and the high resistivity values of these layers ranging from $3415 \Omega \mathrm{m}$ to $4555 \Omega \mathrm{m}$, which is indicative of been saturated with fresh water compared to the low resistivity values of other layers that ranges from $44 \Omega \mathrm{m}$ to $1400 \Omega \mathrm{m}$. Water from two existing wells in the study area with depth of $20 \mathrm{~m}$ and $22 \mathrm{~m}$ appear brackish, which indeed corresponds to the fifth layer with low resistivity values despite the appropriate soil profile of the layer. Again, the density values of the layers are indicative of suitable aquiferous materials.

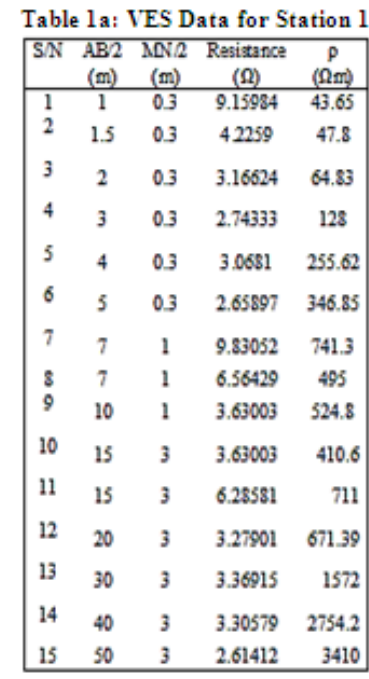

Table 1b: Interpreted Geoelectric layers and resistivitis for VES station 1

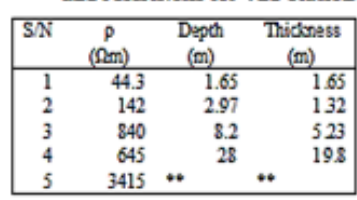

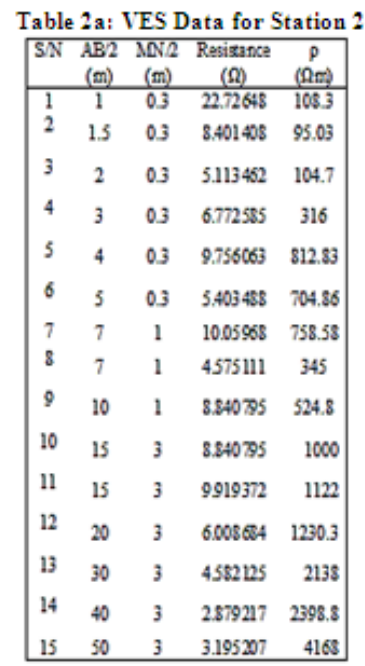

Table 2b: Interpreted Geoelectric layers and resistivities for VIS station 2

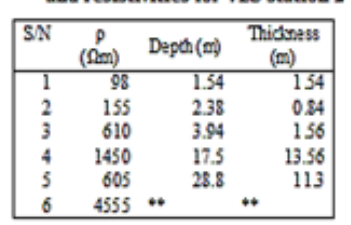

Table 3a: VES Data for Station 3

\begin{tabular}{|c|c|c|c|c|}
\hline , & $\begin{array}{l}\mathrm{AB2} \\
(\mathrm{m})\end{array}$ & $\begin{array}{c}\mathrm{MN/2} \\
(\mathrm{m})\end{array}$ & $\begin{array}{c}\text { Resitance } \\
(\Omega)\end{array}$ & $\begin{array}{c}\rho \\
(\Omega \mathrm{m})\end{array}$ \\
\hline 1 & & 0.3 & & \\
\hline 2 & 1.5 & 0.3 & 11.046 & 124.5 \\
\hline & 2 & 0.3 & 5.4798 & 112 \\
\hline & 3 & 0.3 & 5.3581 & 250 \\
\hline & 4 & 0.3 & .80 & 400 \\
\hline & 5 & 0.3 & 3.4468 & 449.6 \\
\hline & 7 & & 5.7951 & 437 \\
\hline & 7 & 1 & 4442 & 712 \\
\hline & 10 & 1 & 5.4592 & 664.8 \\
\hline & 15 & 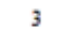 & 5.4592 & 617. \\
\hline 1 & 15 & 3 & 8.08 & 915 \\
\hline & 20 & 3 & 0.5783 & 118. \\
\hline 1 . & 30 & 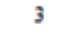 & 3.6949 & 1724 \\
\hline & 40 & & 5304 & 295 \\
\hline & 50 & & 2.500 & \\
\hline
\end{tabular}

Table 3b: Interpreted Geoelectric layers and resistivities for VES station 3

\begin{tabular}{|cccc|}
\hline SN & $\rho$ & $\begin{array}{c}\text { Depdh } \\
(\Omega \mathrm{m})\end{array}$ & $\begin{array}{c}\text { Thicsnoss } \\
(\mathrm{m})\end{array}$ \\
\hline 1 & 985 & 1.5 & 1.5 \\
2 & 195 & 2.4 & 09 \\
3 & 505 & 3.9 & 15 \\
4 & 1360 & 17 & 13.1 \\
5 & 498 & 28 & 11 \\
6 & 3967 & $*$ & $*$ \\
\hline
\end{tabular}

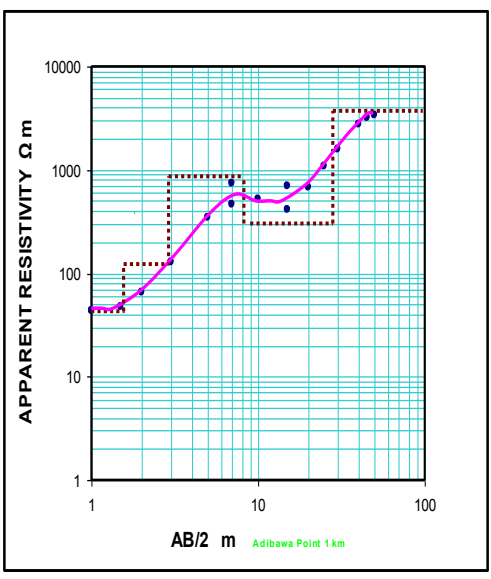

Fig.3: Resistivity Curve for Station 1
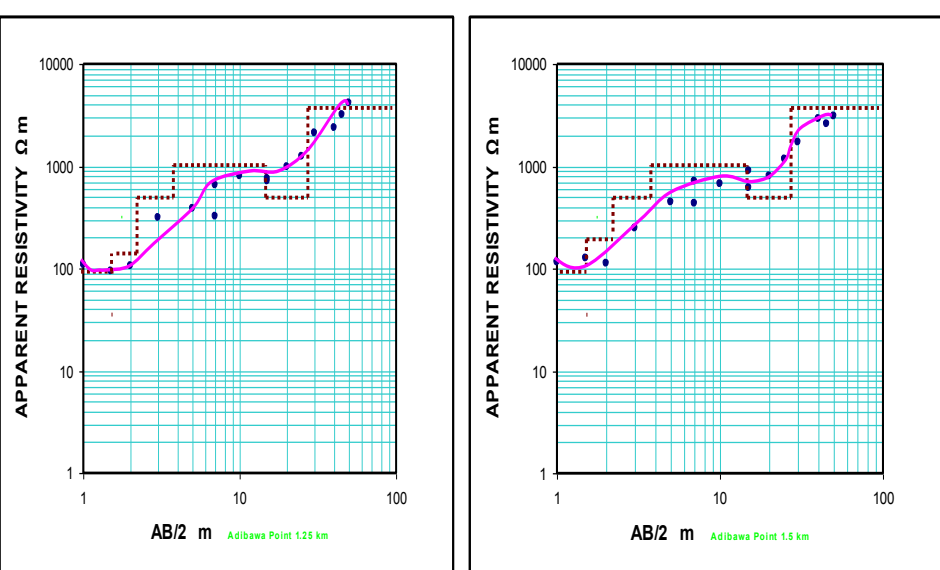

Fig.4: Resistivity Curve for Station 2 Fig.5: Resistivity Curve for Station 3 


Table 4a: VES Data for Station 4
\begin{tabular}{|ccccc|}
\hline S/N & $\begin{array}{c}\text { AB/2 } \\
(\mathrm{m})\end{array}$ & $\begin{array}{c}\text { MNN/2 } \\
(\mathrm{m})\end{array}$ & $\begin{array}{c}\text { Restsance } \\
(\Omega)\end{array}$ & $\begin{array}{c}\rho \\
(\Omega \mathrm{m})\end{array}$ \\
\hline 1 & 1 & 0.3 & 24.1325 & 115 \\
2 & 1.5 & 0.3 & 8.48716 & 96 \\
3 & 2 & 0.3 & 5.22579 & 107 \\
4 & 3 & 0.3 & 6.77258 & 316 \\
5 & 4 & 0.3 & 9.75605 & 812.83 \\
6 & 5 & 0.3 & 5.40349 & 704.86 \\
7 & 7 & 1 & 10.0597 & 758.58 \\
8 & 7 & 1 & 7.20083 & 543 \\
9 & 10 & 1 & 6.22392 & 813 \\
10 & 15 & 3 & 6.22392 & 704 \\
11 & 15 & 3 & 5.99406 & 678 \\
12 & 20 & 3 & 5.61651 & 1150 \\
13 & 30 & 3 & 4.58213 & 2138 \\
14 & 40 & 3 & 2.87922 & 2398.8 \\
15 & 50 & 3 & 2.4723 & 3225 \\
\hline & & & & \\
\hline
\end{tabular}

Table 4b: Interpreted Geoelectric layers and resistivities for VES station 4

\begin{tabular}{|cccc|}
\hline \multicolumn{4}{|c}{ and resistirities for VES station } \\
\hline $\begin{array}{cccc}\rho \\
(\Omega \mathrm{m})\end{array}$ & $\begin{array}{c}\text { Deph } \\
(\mathrm{m})\end{array}$ & $\begin{array}{c}\text { Thidosess } \\
(\mathrm{m})\end{array}$ \\
\hline 1 & 93 & 1.5 & 15 \\
2 & 155 & 2.5 & 1 \\
3 & 610 & 392 & 1.42 \\
4 & 1450 & 17.8 & 13.78 \\
5 & 605 & 29 & 11.2 \\
6 & 4555 & $* *$ & $*$ \\
\hline
\end{tabular}

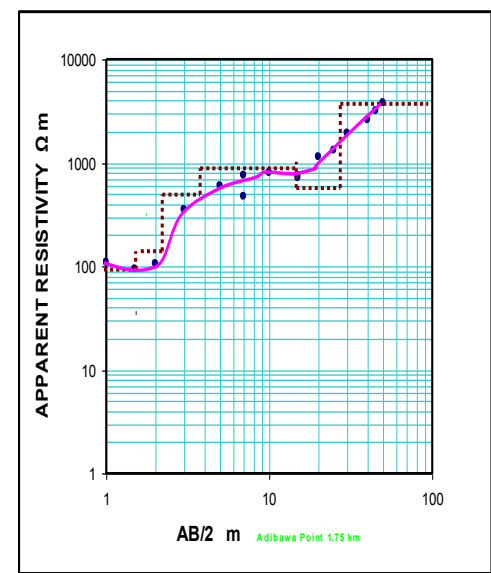

Fig.6: Resistivity Curve for Station 4

\begin{tabular}{|c|c|c|c|c|}
\hline$S / N$ & $\begin{array}{l}A B / 2 \\
(\mathrm{~m})\end{array}$ & $\begin{array}{c}\mathrm{MN/2} / 2 \\
(\mathrm{~m})\end{array}$ & $\begin{array}{c}\text { Retisance } \\
(\Omega)\end{array}$ & $\stackrel{P}{P}$ \\
\hline 1 & 1 & 0.3 & 22.72648 & 108.3 \\
\hline 2 & 1.5 & 0.3 & 8.401408 & 95.03 \\
\hline 3 & 2 & 0.3 & 5.113462 & 104.7 \\
\hline 4 & 3 & 0.3 & 6.772585 & 316 \\
\hline$s$ & 4 & 0.3 & 9.756063 & 812.83 \\
\hline 6 & 5 & 0.3 & 5.403488 & 704.86 \\
\hline 7 & 7 & 1 & 10.05968 & 758.58 \\
\hline 8 & 7 & 1 & 204224 & 154 \\
\hline 9 & 10 & 1 & 8840795 & 524.8 \\
\hline 10 & 15 & 3 & 8.840795 & 1000 \\
\hline 11 & 15 & 3 & 9.74281 & 1102 \\
\hline 12 & 20 & 3 & 6008684 & 1230.3 \\
\hline 13 & 30 & 3 & 4532125 & 2138 \\
\hline 14 & 40 & 3 & 2.879217 & 2398.8 \\
\hline 15 & so & 3 & 3.195207 & 4168 \\
\hline
\end{tabular}

Table 5b: Interpreted Geoelectric layers and resistivities for VES station 5

\begin{tabular}{|cccc|}
\hline S/N & $\begin{array}{c}P \\
(\Omega \mathrm{m})\end{array}$ & $\begin{array}{c}\text { Depch } \\
(\mathrm{m})\end{array}$ & $\begin{array}{c}\text { Thidraas } \\
(\mathrm{m})\end{array}$ \\
\hline 1 & 59 & 3 & 3 \\
2 & 320 & 4.6 & 1.6 \\
3 & 1250 & 15.6 & 11 \\
4 & 498 & 28.7 & 13.1 \\
5 & 3900 & $*$ & $*$ \\
\hline
\end{tabular}

Table 6a: VES Data for Station 6

\begin{tabular}{|c|c|c|c|c|}
\hline$S / N$ & $\begin{array}{l}A B 2 \\
(m)\end{array}$ & $\begin{array}{l}\mathrm{MQN} / 2 \\
(\mathrm{~m})\end{array}$ & $\begin{array}{c}\text { Rmitases } \\
\text { (Q) }\end{array}$ & $\stackrel{p}{\left(\Omega^{\prime}\right)}$ \\
\hline 1 & 1 & 0.3 & 31.4772 & 150 \\
\hline 2 & 1.5 & 0.3 & 8045123 & 91 \\
\hline 3 & 2 & 0.3 & 3.164779 & 64.8 \\
\hline 4 & 3 & 0.3 & 2.636164 & 123 \\
\hline 5 & 4 & 0.3 & 1920414 & 160 \\
\hline 6 & 5 & 0.3 & 1522477 & 198.6 \\
\hline 7 & 7 & 1 & 2.652239 & 200 \\
\hline 8 & 7 & 1 & 4.669266 & 352.1 \\
\hline 9 & 10 & 1 & 3.612172 & 391.31 \\
\hline 10 & 15 & 3 & 3.612172 & 408.58 \\
\hline 11 & is & 3 & 6913502 & 782 \\
\hline 12 & 20 & 3 & 2.62364 & 537.2 \\
\hline 13 & 30 & 3 & 3.103644 & 1448.1 \\
\hline 14 & 40 & 3 & 3.601977 & 3001 \\
\hline is & so & 3 & 3.07021 & 4005 \\
\hline
\end{tabular}

Table 6b: Interpreted Geoelectric layers and resistirities for VES station 6

\begin{tabular}{|cccc|}
\hline SN & $\begin{array}{c}p \\
(\Omega \mathrm{m})\end{array}$ & $\begin{array}{c}\text { Depoh } \\
(\mathrm{m})\end{array}$ & $\begin{array}{c}\text { Tidoness } \\
(\mathrm{m})\end{array}$ \\
\hline 1 & 79.5 & 294 & 2.94 \\
2 & 315 & 496 & 2.02 \\
3 & 1180 & 16 & 11.04 \\
4 & 506 & 25 & 9 \\
5 & 3996 & $*$ & $*$ \\
\hline
\end{tabular}

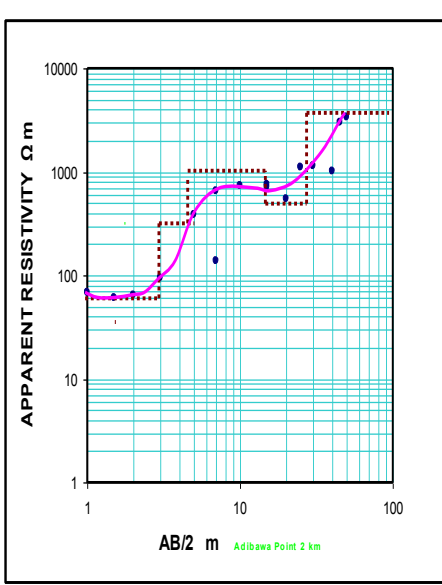

Fig.7: Resistivity Curve for Station 5 for Station 6

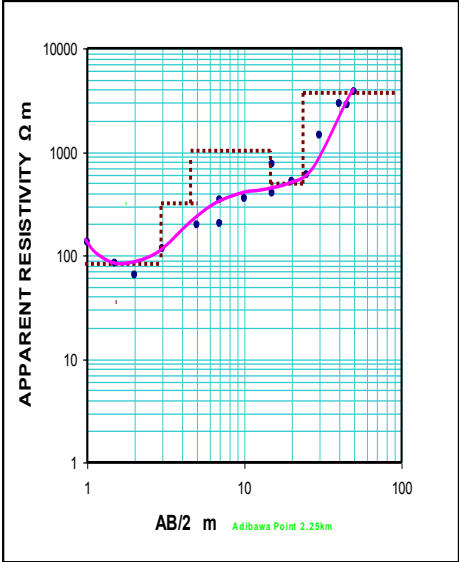

Fig.8: Resistivity Curve 
Table 7a: VES Data for Station 7

\begin{tabular}{|ccccc|}
\hline $\mathrm{S} / \mathrm{N}$ & $\begin{array}{c}\mathrm{AB} / 2 \\
(\mathrm{~m})\end{array}$ & $\begin{array}{c}\mathrm{MN} / 2 \\
(\mathrm{~m})\end{array}$ & $\begin{array}{c}\text { Resistance } \\
(\Omega)\end{array}$ & $\begin{array}{c}\rho \\
(\Omega \mathrm{m})\end{array}$ \\
\hline 1 & 1 & 0.3 & 38.192 & 182 \\
2 & 1.5 & 0.3 & 14.764 & 167 \\
3 & 2 & 0.3 & 3.1648 & 64.8 \\
4 & 3 & 0.3 & 3.8792 & 181 \\
5 & 4 & 0.3 & 4.8076 & 400.55 \\
6 & 5 & 0.3 & 3.2954 & 429.87 \\
7 & 7 & 1 & 3.3738 & 254.41 \\
8 & 7 & 1 & 5.3208 & 401.23 \\
9 & 10 & 1 & 4.1963 & 306.34 \\
10 & 15 & 3 & 4.1963 & 474.65 \\
11 & 15 & 3 & 3.1572 & 357.12 \\
12 & 20 & 3 & 2.1733 & 445 \\
13 & 30 & 3 & 3.0682 & 1431.6 \\
14 & 40 & 3 & 29346 & 2445 \\
15 & 50 & 3 & 2.5528 & 3330 \\
\hline
\end{tabular}

Table 7b: Interpreted Geoelectric layers and resistivities for VES station 7

\begin{tabular}{|cccc|}
\hline $\mathrm{S} / \mathrm{N}$ & $\begin{array}{c}\rho \\
(\mathrm{m})\end{array}$ & $\begin{array}{c}\text { Depth } \\
(\mathrm{m})\end{array}$ & $\begin{array}{c}\text { Thidones } \\
(\mathrm{m})\end{array}$ \\
\hline 1 & 182 & 15 & 15 \\
2 & 113 & 3.7 & 2.2 \\
3 & 600 & 10.5 & 6.8 \\
4 & 220 & 18.6 & 8.1 \\
5 & 1250 & 29.6 & 12 \\
6 & 3996.9 & $*$ & $*$ \\
\hline
\end{tabular}

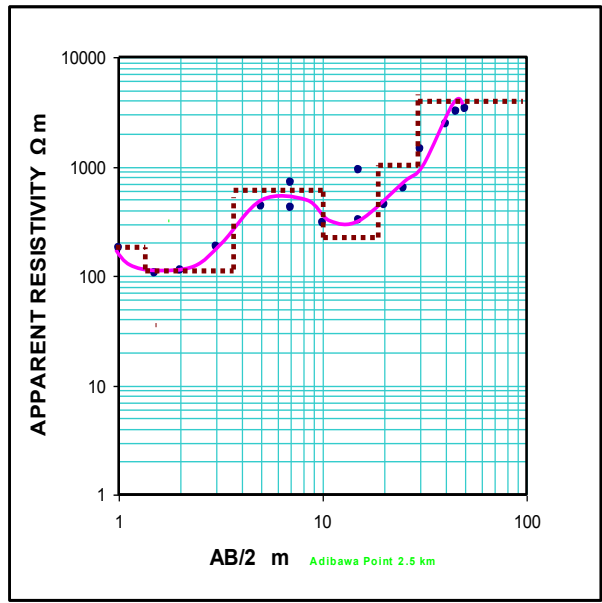

Fig.9: Resistivity Curve for Station 7
Table \&a: VES Data for Station \&

\begin{tabular}{|c|c|c|c|c|}
\hline $\mathrm{S} / \mathrm{N}$ & $\begin{array}{l}A B / 2 \\
(m)\end{array}$ & $\begin{array}{l}\mathrm{MN} / 2 \\
(\mathrm{~m})\end{array}$ & $\begin{array}{c}\text { Resietance } \\
(\Omega)\end{array}$ & $\stackrel{\rho}{\rho}$ \\
\hline 1 & 1 & 0.3 & 24.174 & 115.2 \\
\hline 2 & 1.5 & 0.3 & 7.5589 & 85.5 \\
\hline 3 & 2 & 0.3 & 3.1648 & 64.8 \\
\hline 4 & 3 & 0.3 & 1.616 & 75.4 \\
\hline$s$ & 4 & 0.3 & 22565 & 188 \\
\hline 6 & 5 & 0.3 & 1.6789 & 219 \\
\hline 7 & 7 & 1 & 3.554 & 268 \\
\hline 8 & 7 & 1 & 5.4783 & 413.11 \\
\hline 9 & 10 & 1 & 2.559 & 398 \\
\hline 10 & 15 & 3 & 29122 & 329.4 \\
\hline 11 & 15 & 3 & 3.7397 & 423 \\
\hline 12 & 20 & 3 & 3.4771 & 711.95 \\
\hline 13 & 30 & 3 & 19379 & 904.2 \\
\hline 14 & 40 & 3 & 1.1066 & 921.97 \\
\hline 15 & so & 3 & 2.1603 & 2818 \\
\hline
\end{tabular}

Table 8b: Interpreted Geoelectric layers and resistivities for VES station 8

\begin{tabular}{|cccc|}
\hline $\mathrm{S} / \mathrm{N}$ & $\begin{array}{c}\rho \\
(\Omega \mathrm{m})\end{array}$ & $\begin{array}{c}\text { Depth } \\
(\mathrm{m})\end{array}$ & $\begin{array}{c}\text { Thichness } \\
(\mathrm{m})\end{array}$ \\
\hline 1 & 79.5 & 2.94 & 2.94 \\
2 & 315 & 7.04 & 4.1 \\
3 & 1400 & 12.64 & 5.6 \\
4 & 1000 & 27.64 & 15 \\
5 & 3996 & $* 4$ & $* 4$ \\
\hline
\end{tabular}

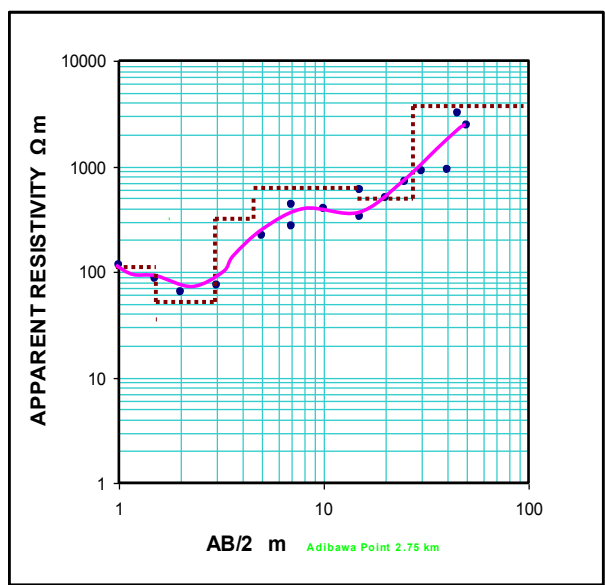

Fig.10: Resistivity Curve for Station 8 


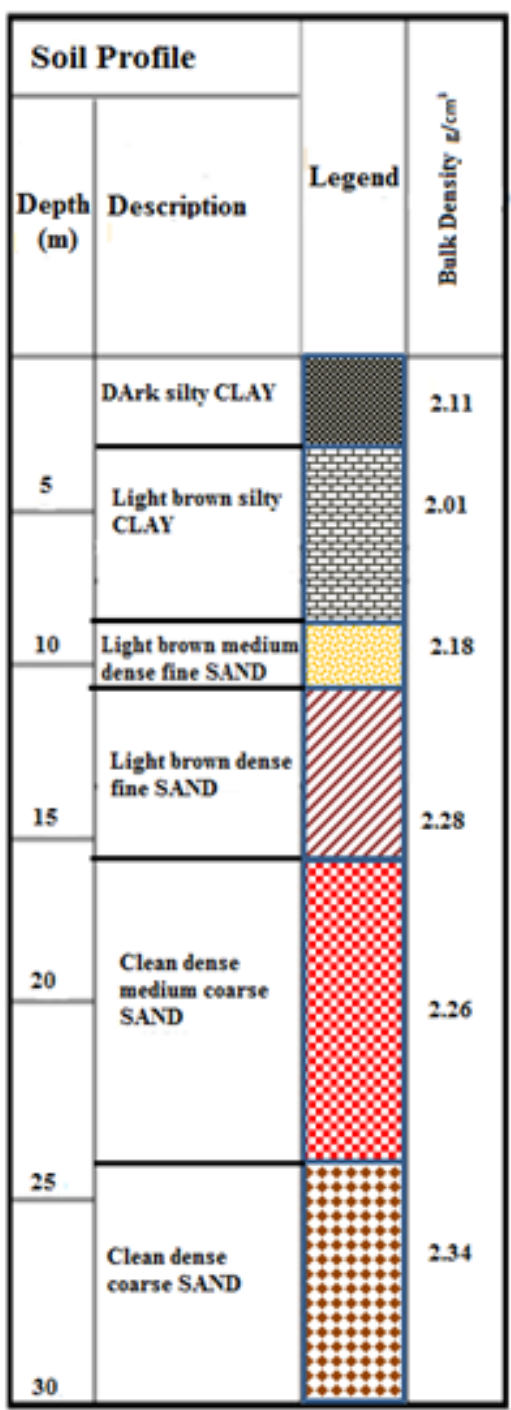

Fig. 11: Borehole Log by physical sampling during drilling for well 1 along profile NM

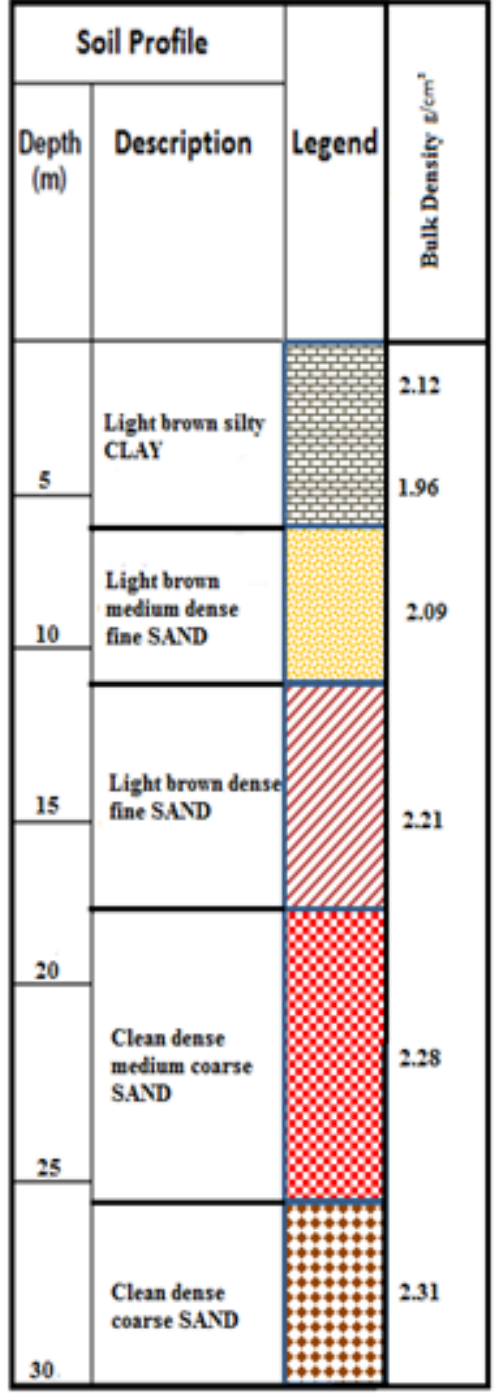

Fig. 12: Borehole Log by physical sampling during drilling for well 2 along profile OP

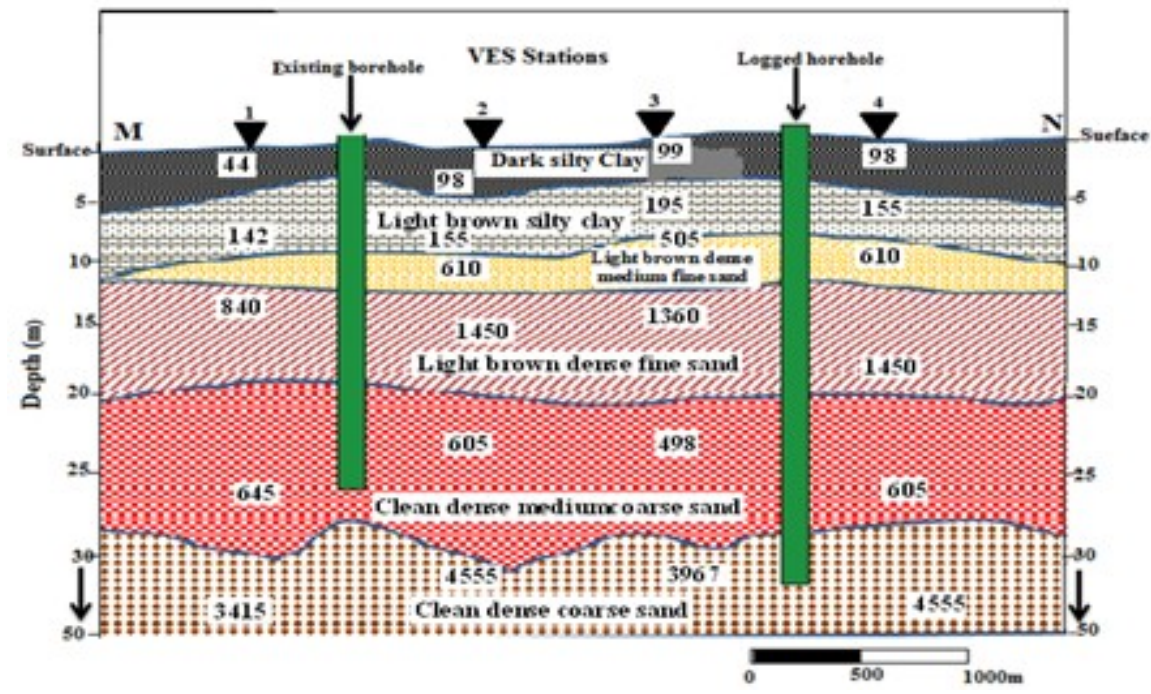

Fig. 13: Geoelectrical cross-section of profile MN 


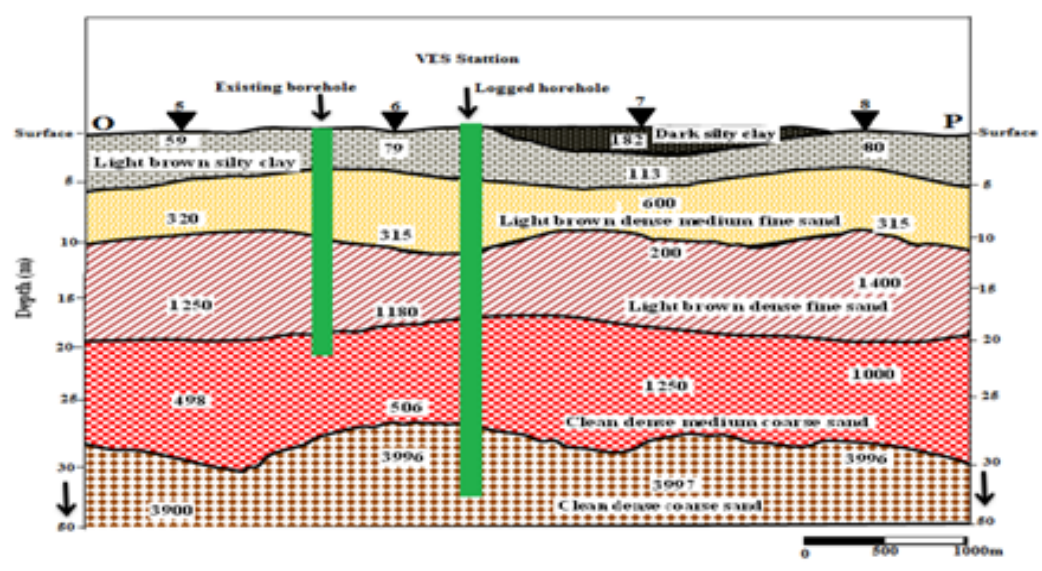

Fig. 14: Geoelectrical cross-section of profile OP

\section{Conclusion}

The results of the geoelectric survey were tied to various lithologies by calibrating the geoelectric values with borehole data. The resistivity variation at various depths and the soil profile reveals that resistivity of any given layer is seriously influenced by the soil or rock materials and the fluid content contained therein. The application of a fast computer iterative procedure aided in obtaining interpreted depths and resistivities from field data by shifted electrode spacing and adjusted apparent resistivities. This investigation was carried out to have relevant data handy before commencement of any applicable project to precisely establish the aquiferous saturated zone to saving cost on the actual project during borehole drilling and locating exact depth to place the screen during well completion processes.

From the findings of this work, the groundwater potentials of Omoku and its environs are enormous based on the positive indicators of high resistivity values, clean coarse sand formation materials, the thickness of the established aquiferous saturated zone and the shallow depth to locating the aquifer, which is about from $22 \mathrm{~m}$ that can facilitate the easy harnessing and supply of safe, sustainable and portable water to the people of the area. The investigation shows that VES method is cheap, easy and reliable to solving some hydrogeological issues of developing countries that are faces with short supply of clean and safe water.

\section{Acknowledgement}

We the authors are thankful to Mrs. Jane Iyeneomie and IYETAMS Ventures Nig. Ltd; for the proofreading and typesetting of this work. We are also thankful to the management of Berebupakabo Company Ltd and Kuluma Waters Ltd., for their support of this work.

\section{References}

[1]. D.K. Todd, Groundwater Hydrology (John Wiley and Sons, Inc. New York, 1959).

[2]. S. Krivochieva, and M. Chouteau, Integrating TDEM and MT methods for characterization and delineation of the Santa Catarina aquifer (Chalco Sub-Basin, Mexico), Journal of Applied Geophysics 52 (2003) 23- 43

[3]. I. Tamunobereton-ari, V.B. Omubo-Pepple, and E.D. Uko, The Influence of Lithology and Depth on Acoustic Velocities in SouthEast Niger Delta, Nigeria. American Journal of Scientific and Industrial Research, 1(2), 2010a, $279-292$.

[4]. I. Tamunobereton-ari, E.D. Uko, and V.B. Omubo-Pepple. Anthropogenic activities- Implications for groundwater resource in Okrika, Rivers State, Nigeria. Research Journal of Applied Sciences. 5(3), 2010b, 204-211.

[5]. N. E. Edlefsen, and A. B. C. Anderson.. The four-electrode resistance method for measuring soil-moisture content under field conditions. Soil Sci. 51, 1941, 367-376.

[6]. I.Tamunobereton-ari, E.D Uko, and Davies, D.H. Prediction of Water Resource Potentials and Sustainable Supply of Water in Port Harcourt, Nigeria from Meteorological Data. International Journal of Engineering and Science (IJES). 2(1), 2013, 222-231.

[7]. B.J. Alloway, and D.C. Ayres. Chemical Principles of Environmental Pollution, (2nd Ed, Glasgow, UK, Blackie Academic \& Professional, 1997).

[8]. A. A. R. Zohdy, L. A., Anderson, and L. P. J., Mufler. Resistivity, self-potential, and induced polarization surveys of a vapor dominated geothermal system, Geophysics, 38, 1973, 1130-1144.

[9]. O. Koefoed, and F.J.H. Dirk, Determination of resistivity sounding filters by the Wiener Hopf Least square method. Geophys. Prospect. 27, 1979, $245-250$.

[10]. A. A. R ., Zohdy, 1968, The effect of current leakage and electrode spacing errors on resistivity measurements: U. S. Geol. Surv. Prof. paper 600D, D258-D264.

[11]. W. H.McCorkle, Determination of soil moisture by the method of multiple electrodes. Tex. Agr. Exp. Sta. Bul, 1931, 426.

[12]. S. C. Gupta, and R. J. Hanks. Influence of water content on electrical conductivity of the soil. Soil Sci. Soc. Am. Proc. 36, 1972, 855-857.

[13]. R. D.Baker. Depth of investigation of collinear symmetrical four-electrode arrays. Geophysics. 54, 1989, 1031-1037.

[14]. O. Banton, M. K. Seguin, and M. A. Cimon. Mapping field-scale physical properties of soil with electrical resistivity. Soil Sci. Soc. Am. J. 61, 1997, 1010-1017. 